\title{
Allocation of Improvement Strategies in a Flow Shop with Two Capacity Constrained Resources
}

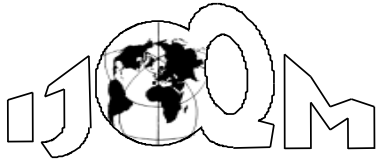

DOI: $10.46970 / 2020.26 .2 .1$

Volume 26, Number 2

June 2020, pp. 79-93
Marcel Heimar Ribeiro Utiyama

Fernanda Caveiro Correia

Dário Henrique Alliprandiniis

FEI University, Brasil

(mutiyama@fei.edu.br)

(fernandacaveiro_correia@hotmail.com)

(dario.allip@fei.edu.br)

The main goal of this paper is to identify the best strategy to allocate improvement programs in a flow shop with two capacity constrained resources. We collected data from a manufacturing company, and we used them to conduct a simulation with the System Dynamics-Factory Physics model. The main variables considered were the mean time between failures and the mean time to repair, and lead time was the output. Strategies used are mainly focused, distributed, and hybrid. Findings show the effect of the allocation of different improvement strategies on lead time reduction. We indicated that for the flow shop analyzed the focused strategies delivered the best results. When it is not possible to perform a large investment in the capacity-constrained resource, companies should use hybrid approaches. An important contribution is a hybrid approach, which is a new way of directing efforts of improvements. Results showed that both strategies, hybrid time to repair improvement and hybrid time between failures improvement, delivered better results compared to the respective distributed strategies.

Keywords: Improvement Allocation, Mean Time to Repair, Hybrid Strategy, Mean Time between Failures, Capacity-Constrained Resource, Lead Time

\section{Introduction}

In today's unpredictable business environment, manufacturing enterprises have faced several challenges to meet ever-increasing customer requires and demands, and to provide more customized products at the most cost-effective price (Adane et al., 2019). One variable that has a direct impact on many of the customer requirements is the lead time. This variable is the focus of different manufacturing strategies, for instance, Lean Manufacturing (Womack et al., 1990) and Quick Response Manufacturing (1998).

Ericksen et al. (2007) define lead time as the total time, in hours, between the client order, passing for all production process; to the first piece arrive in the client. Lead time can be defined as the total time between purchase and delivery to the customer (Christopher, 1992). With these definitions, it is possible to understand how reducing lead time can affect the cost, delivery time, and flexibility. This way it is comprehensive the reason why many manufacturing strategies focus on their improvement.

According to Godinho Filho and Utiyama (2015), there are three main strategies for improvement programs: focused, distributed, and hybrid. The first one, the 
focused approach where improvement is focused on the capacity constraint resource, this approach is based in the Theory of Constraints (Goldratt, 2009). The second, distributed approach where improvement is distributed in all resources, this approach is based on the lean manufacturing strategy. The last one, the hybrid strategy that is a combination of the focused and distributed.

The importance of the correct allocation of the improvement program was studied in recent papers (Godinho Filho and Utiyama, 2015; Renna, 2017; Renna and Ambrico, 2019). Nonetheless, the literature about the allocation of improvement programs does not analyze the problem of allocation when the flow shop process has two capacity constrained resources. This is a research gap that is studied in this paper. We also, analyze and propose different configurations of the hybrid strategy of performing improvement programs.

The main goal of this paper is to identify the best improvement strategy in a flow shop with two capacity constrained resources. Also, we investigated different variations of the three strategies for allocation of improvement programs and highlight the importance of hybrid strategies. This paper is organized in six sections; besides this first section; Section 2 is the overview of the literature used; Section 3 explains the simulation model used in this paper; Section 4 shows the allocation improvement policies; Section 5 presents the results of simulation; and Section 6 shows the conclusions of this paper.

\subsection{The Effect of Improvement Programs}

\section{Literature Review}

Six variables have strong impact in lead time, there are: processing time variability; mean setup time; arrival variability; processing time variability; mean defect rate; mean time between failure; mean repair time. These variables involve two parameters, variability, which can be measured in terms of the coefficient of variation, equation 1, and mean rate (Hopp and Spearman, 2008).

$$
c_{d}=\sqrt{u^{2} c_{e}^{2}+\left(1-u^{2}\right) c_{a}^{2}}
$$

where,

$\mathrm{U}$ is utilization of the workstation $\mathrm{I}$,

ce(i) is $\mathrm{cv}$ of the effective processing time of workstation i,

$\mathrm{ca}(\mathrm{i})$ is $\mathrm{cv}$ of the inter-arrival time between lots of workstation i.

In this study we mainly analyzed two variables, the mean time between failures and the mean repair time. The mean time between failures can be defined as the mean interval time between two consecutives failures in one machine, usually it is measured in operation hours, in a defined environment (Martins and Laugeni, 2006). The mean repair time, that can be understood as the mean time used to fix an equipment, since it broke until it is working again (Slack et al, 2010). These two variables together measure the availability of a resource and are investigated in several recent papers (Fisel et al., 2019; Alfineto et al., 2019). An improvement in these two variables can increase machine availability, because it improves capacity (Hopp and Spearman, 2008). 
Unplanned machine failures are one of the greatest sources of variability in many manufacturing operations and reduce the availability of a resource. This reduction in the availability impacts the capacity of a resource and can increase the lead time. So, it is fundamental that a company perform improvements in the repair time and in the time between failures to increase availability and reduce lead time.

\subsection{Allocation Improvement Strategies}

After a literature review about improvement strategy in lead time was possible to create Table 1 that, summarize the main papers published in the area.

Table 1 Summary of Previous Studies in Improvement Policies

\begin{tabular}{|c|c|c|}
\hline Authors & Variables & Summary \\
\hline $\begin{array}{l}\text { Hong and } \\
\text { Hayya (1995) }\end{array}$ & Setup and quality & $\begin{array}{l}\text { The authors investigate different forms of allocating } \\
\text { improvement programs of setup and quality. They } \\
\text { conclude that it is favored to invest in quality } \\
\text { improvement or reduction in setup before any joint } \\
\text { investment. }\end{array}$ \\
\hline $\begin{array}{l}\text { Hadjinicola } \\
\text { and Soteriou } \\
(2003)\end{array}$ & Yield and annual cost & $\begin{array}{l}\text { The authors investigated how should be allocated the } \\
\text { limited capital resources to the various stages of a } \\
\text { multistage production system in order to improve the } \\
\text { yield of the production stages and, at the same time, } \\
\text { minimize the annual cost incurred from defects. }\end{array}$ \\
\hline $\begin{array}{l}\text { Rau et al. } \\
(2005)\end{array}$ & Quality & $\begin{array}{l}\text { The paper study quality inspection allocation in re- } \\
\text { entrant production systems. It offers a heuristic } \\
\text { algorithm that assists in the allocation of quality } \\
\text { inspection. The proposed algorithm involves five steps } \\
\text { to find the workstation with the highest process cost, } \\
\text { the highest rate of defects and the highest layer effect } \\
\text { and then calculates which alternative allocation of } \\
\text { quality inspection gain more profit. }\end{array}$ \\
\hline $\begin{array}{l}\text { Blackstone Jr. } \\
\text { and Cox } \\
(2002)\end{array}$ & $\begin{array}{l}\text { Work in progress } \\
\text { (WIP) }\end{array}$ & $\begin{array}{l}\text { The authors discuss protective capacity allocation as } \\
\text { the capacity necessary at non-constraint workstations } \\
\text { to restore the WIP inventory to the location adjacent to } \\
\text { and upstream from the constraint workstation to } \\
\text { support full utilization of the CCR. }\end{array}$ \\
\hline $\begin{array}{l}\text { Caridi et al. } \\
(2006)\end{array}$ & CCR position & $\begin{array}{l}\text { The study suggests that when the system variability is } \\
\text { high, the best option is to place the CCR at the } \\
\text { beginning of the production line; however, when the } \\
\text { availability is low, it is preferable to place the CCR at } \\
\text { the end of the line. }\end{array}$ \\
\hline $\begin{array}{l}\text { Craighead et } \\
\text { al. }(2001)\end{array}$ & Protective capacity & $\begin{array}{l}\text { The authors enquire about allocation of protective } \\
\text { capacity along a flow shop environment with five } \\
\text { workstations using a simulation. The results express } \\
\text { that there is practically no effect on flow time } \\
\text { according to the protective capacity location; however, } \\
\text { protective capacity significantly affects the tendency } \\
\text { of bottleneck shiftiness. }\end{array}$ \\
\hline $\begin{array}{l}\text { Betterton Jr. } \\
\text { and Cox } \\
(2008)\end{array}$ & CCR position & $\begin{array}{l}\text { The research exhibit that in a flow shop environment } \\
\text { with four workstations, there is no significant } \\
\text { difference in process performance according to CCR } \\
\text { location. }\end{array}$ \\
\hline
\end{tabular}




\begin{tabular}{|c|c|c|}
\hline $\begin{array}{l}\text { Godinho Filho } \\
\text { and Uzsoy } \\
(2011)\end{array}$ & Lot size and cycle time & $\begin{array}{l}\text { The authors used a system dynamics model based on } \\
\text { the factory physics equations to investigate the effect } \\
\text { of many continuous improvement programs on the } \\
\text { relationship between lot sizes and cycle times. It } \\
\text { shows that the relationship between lot sizes, cycle } \\
\text { times and shop floor parameters is complex and } \\
\text { nonlinear. Reduction of lot size can have a significant } \\
\text { benefit in cycle time; conversely, an incorrect choice } \\
\text { of lot sizes can have a negative effect on the benefits } \\
\text { of a continuous improvement programs. Although the } \\
\text { biggest cycle time reduction is accomplished by a } \\
\text { large reduction in setup time, the same benefits can be } \\
\text { obtained with some small, simultaneous improvements } \\
\text { in combined variables. }\end{array}$ \\
\hline $\begin{array}{l}\text { Godinho Filho } \\
\text { and Uzsoy } \\
(2012)\end{array}$ & $\begin{array}{l}\text { Time to repair and } \\
\text { setup time }\end{array}$ & $\begin{array}{l}\text { The research investigated the cumulative effects of } \\
\text { continuous improvement programs for repair and setup } \\
\text { times on the cycle time for a simple single-stage } \\
\text { production system. It detected that small } \\
\text { improvements in multiple areas has greater cumulative } \\
\text { benefits over time comparing with a large reduction in } \\
\text { a single parameter, specifically when there is } \\
\text { significant uncertainty about the extension of } \\
\text { improvement that can be obtained or in the degree to } \\
\text { which improvements can be sustained over time. }\end{array}$ \\
\hline $\begin{array}{l}\text { Guimaraes et } \\
\text { al. (2013) }\end{array}$ & $\begin{array}{l}\text { Setup time, defect rate, } \\
\text { time to repair, time } \\
\text { between failures, } \\
\text { processing time } \\
\text { variability and arrival } \\
\text { variability }\end{array}$ & $\begin{array}{l}\text { The study analyzed the effect of six shop floor } \\
\text { improvement program on lead time for many } \\
\text { production system characteristics. As conclusion it } \\
\text { demonstrates that all improvement program showed } \\
\text { significant contributions for lead time reduction in at } \\
\text { least some production environments studied, except } \\
\text { improvement in the arrival coefficient. The } \\
\text { experimental results also showed that improvement in } \\
\text { the time between failures was the program that } \\
\text { presented a significant positive effect on lead time } \\
\text { reduction. }\end{array}$ \\
\hline $\begin{array}{l}\text { Godinho Filho } \\
\text { and Uzsoy } \\
(2013)\end{array}$ & $\begin{array}{l}\text { Processing variability, } \\
\text { mean setup time, mean } \\
\text { repair time and mean } \\
\text { time between failures }\end{array}$ & $\begin{array}{l}\text { The paper presents the cumulative effect of continuous } \\
\text { improvement in arrival variability, process variability, } \\
\text { defect rate, time to failure, repair time and setup time } \\
\text { on operating curves in a flow shop environment. For } \\
\text { their best improvement program the researchers } \\
\text { investigated focused strategy in one resource against a } \\
\text { distribute strategy in all resource. As results it indicate } \\
\text { that for a balanced line when utilization is low (below } \\
85 \% \text { ), there is almost no difference between the two } \\
\text { strategies for any of the four improvement program } \\
\text { studied. As utilization increases above } 90 \% \text {, the } \\
\text { distribute strategy is better for the mean setup time, } \\
\text { mean repair time and mean time between failures. In } \\
\text { addition, the researchers compared a 50\% } \\
\text { improvement in setup time at the bottleneck and a } 10 \% \\
\text { improvement in setup time in all workstations for an } \\
\text { unbalanced line. They conclude that for low utilization }\end{array}$ \\
\hline
\end{tabular}




\begin{tabular}{|c|c|c|}
\hline & & $\begin{array}{l}\text { levels, both policies have almost the same results; as } \\
\text { utilization increases (above } 80 \% \text { ), investing in the } \\
\text { bottleneck becomes the preferable option. }\end{array}$ \\
\hline $\begin{array}{l}\text { Godinho Filho } \\
\text { and Utiyama } \\
(2016)\end{array}$ & $\begin{array}{l}\text { Setup time, defect rate, } \\
\text { time to repair, time } \\
\text { between failures, } \\
\text { processing time } \\
\text { variability and arrival } \\
\text { variability }\end{array}$ & $\begin{array}{l}\text { The authors define three classes of improvement } \\
\text { strategies. The first strategy, the focused strategy, } \\
\text { concentrates on the capacity constraint resource } \\
\text { (CCR). The second strategy, the distributed strategy, } \\
\text { advocates making improvements to all workstations on } \\
\text { the production line. A third option, called hybrid } \\
\text { strategy, for improvement is actually a combination of } \\
\text { these two previous strategies. }\end{array}$ \\
\hline $\begin{array}{l}\text { Godinho Filho } \\
\text { and Barco } \\
(2015)\end{array}$ & $\begin{array}{l}\text { Setup time, defect rate, } \\
\text { time to repair, time } \\
\text { between failures, } \\
\text { processing time } \\
\text { variability and arrival } \\
\text { variability }\end{array}$ & $\begin{array}{l}\text { The paper proposed a practical framework for } \\
\text { choosing among different improvement programs in a } \\
\text { one-machine environment. They applied the } \\
\text { framework in an aeronautics company process with a } \\
\text { single machine and machining process bottleneck, the } \\
\text { application of the proposed framework resulted in a } \\
\text { potential } 84.63 \% \text { improvement in lead time, which } \\
\text { was obtained by improving the mean time between } \\
\text { failures by } 1373 \% \text { and required an effort of } 5880 \mathrm{~h} \text {. } \\
\text { Alternatively, a } 34.76 \% \text { reduction in lead time was } \\
\text { achieved through a } 1960 \text {-h investment in labor; this } \\
\text { improved the coefficient of variation of repair time by } \\
72 \% \text {. }\end{array}$ \\
\hline Renna (2017) & Due data and capacity & $\begin{array}{l}\text { Proposed a policy to improve the due date } \\
\text { performance by the capacity improvement program } \\
\text { among different production lines. The policy concerns } \\
\text { the estimation of delay or early of parts due date in } \\
\text { queue and the shifting of capacity among the } \\
\text { manufacturing lines is based on this estimation. }\end{array}$ \\
\hline $\begin{array}{l}\text { Utiyama, } \\
\text { Moura and } \\
\text { Costa }(2017)\end{array}$ & $\begin{array}{l}\text { Setup time ,time to } \\
\text { repair and availability. }\end{array}$ & $\begin{array}{l}\text { The paper studied a flowshop environment with one } \\
\text { CCR. They investigated three strategies: a focused } \\
\text { improvement in the setup time; a focused } \\
\text { improvement in time to repair; a focused improvement } \\
\text { in both variables. The study concluded that each } \\
\text { strategy results are related to CCR availability. For } \\
\text { more than } 95 \% \text { of availability in the CCR the best } \\
\text { strategy was the focused in the setup time, when it is } \\
\text { exact } 95 \% \text { the best policy is focused in both variables } \\
\text { and when below } 95 \% \text { the best policy is focused in the } \\
\text { time to repair. }\end{array}$ \\
\hline $\begin{array}{l}\text { Alfineto; } \\
\text { Amancio, } \\
\text { Rosaand } \\
\text { Utiyama } \\
(2019)\end{array}$ & $\begin{array}{l}\text { Time between failure, } \\
\text { time to repair and } \\
\text { setup time }\end{array}$ & $\begin{array}{l}\text { The authors studded the focused, distributed and } \\
\text { hybrid strategy combining two variables at the time. } \\
\text { The first two variables used in the study was time } \\
\text { between failure and time to repair, follow by the time } \\
\text { to repair and setup time. It concludes that the hybrid } \\
\text { strategy was the best, but dependent of the time to } \\
\text { repair a different approach is better. }\end{array}$ \\
\hline $\begin{array}{l}\text { Rennaand } \\
\text { Ambrico } \\
(2019)\end{array}$ & $\begin{array}{l}\text { Throughput, lead time, } \\
\text { work in process, defect } \\
\text { rate. }\end{array}$ & $\begin{array}{l}\text { The paper proposes a multi-dimension simulation } \\
\text { environment to test improvement programs in a flow } \\
\text { shop context. The tested the three programs proposed } \\
\text { in the literature: centralized, distributed and hybrid. } \\
\text { The simulation results show how the centralized policy }\end{array}$ \\
\hline
\end{tabular}




\begin{tabular}{|l|l|l|}
\hline & $\begin{array}{l}\text { is the better in a single product case, while the hybrid } \\
\text { policy leads to the better results in case of multi- } \\
\text { products. }\end{array}$ \\
\hline $\begin{array}{l}\text { Fisel et al. } \\
(2019)\end{array}$ & $\begin{array}{l}\text { Fle paper states that the existing approaches do not } \\
\text { consider the reallocation of assembly tasks or the } \\
\text { dimensioning of system-inherent flexibility and } \\
\text { changeability. } \\
\text { proposed an approach which aimed at optimizing the } \\
\text { line balancing of flow assembly systems, considering } \\
\text { the potential need for adaptation in order to meet the } \\
\text { requirements of uncertain planning environments. }\end{array}$ \\
\hline
\end{tabular}

As showed in Table 1 the theme has been researched in the past few years. Nonetheless, the problem which is the best improvement strategy in a flow shop with two capacity constrained resources is already not addressed. Section 3 presents the method used and the experiments conducted.

\section{Modelling and Experiments}

The model used combines the strengths of the holistic approach of System Dynamics (Forrester, 1961), which has been used in a great number of papers (Adane et al., 2019; Betterton and Cox, 2008; Godinho Filho and Uzsoy, 2012) and the mathematical fundamental equations proposed by the Factory Physics (Hopp and Spearman, 2008) approach. The combination of the two approaches forms the System Dynamics-Factory Physics model developed by Godinho Filho and Uzsoy (2011) and already used in several papers (Guimaraes et al., 2013,;Godinho Filho and Uzsoy, 2013; Godinho Filho and Utiyama, 2016).

The model considers that each workstation with one single machine, classified as G/G/1 queue, and the production line processes four types of one product. For this study, the simulations were run using the Vensim software, in an Intel i7 notebook with $8 \mathrm{~GB}$ of RAM. To elaborate the experiments, we create the following assumption: a focused improvement of $25 \%$ is similar in terms of financial investment to a $10 \%$ improvement in seven resources. This strategy assumes that a small improvement toward all the investigated line is cheaper and easier to implement than a largely focused improvement. Godinho Filho and Utiyama (2015) followed a similar idea, where they consider that in financial terms the investment to improve $50 \%$ one resource is similar to $10 \%$ of improvement in five resources. The authors recognized that this comparison might not be accurate since there is a limitation on how much improvement can be done in one variable and how this impact in the financial investment is required.

As a result, it was created ten different scenarios based on the focused improvement of $25 \%$, distributed improvement of $10 \%$ in each machine, and a hybrid improvement of $25 \%$ divided by the machines until de capacity constraint resource and focused improvement of $25 \%$ combined towards the two CCRs. Figure 1 illustrates the different strategies. 


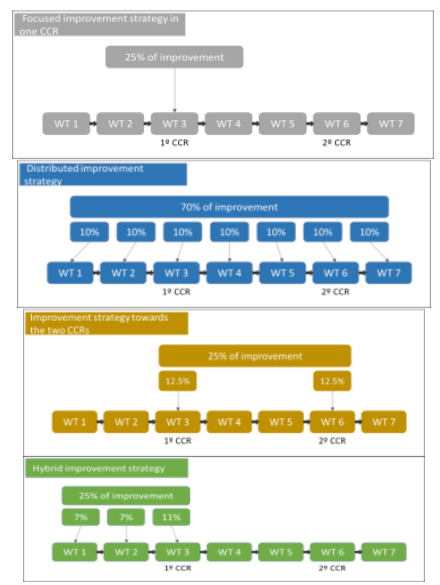

Figure 1 The Three Strategies of Improvement Allocation

The ten scenarios are

1. Focused time to repair improvement: This strategy aims to improve $25 \%$ in the time to repair on the capacity constraint resource.

2. The focused time between failure improvement: This strategy aims to improve $25 \%$ in time between failure on the capacity-constrained resource.

3. Distributed time to repair improvement: This strategy aims to improve $10 \%$ in time to repair distributed to the seven resources.

4. The distributed time between failure improvement: This strategy aims to improve $10 \%$ in time between failure distributed to the seven resources.

5. Focused time to repair and time between failure improvement: This strategy aims to make a joint improvement of $12.5 \%$ in time to repair and also in time between failure only at the capacity-constrained resource.

6. Distributed time to repair and between failure improvement: This strategy aims to make a joint improvement of $5 \%$ in time to repair and also in time between failure at each resource.

7. Hybrid time to repair improvement: This strategy aims to improve the time to repair in $7 \%$ on the two first resources, and in $11 \%$ at the third resource. This logic is because the CCR with higher utilization is the third resource. So the hybrid strategy aims to improve the workstations before and the CCR itself. The large part of the $25 \%$ percentage of improvement was allocated to the CCR because it was assumed that this would be the most effective way to use this hybrid approach.

8. The hybrid time between failure improvements: This strategy aims to improve the time between failure in $7 \%$ on the two first resources, and in $11 \%$ at the third resource.

9. Time to repair improvement strategy towards the two CCRs: This strategy aims to improve time to repair in $12.5 \%$ at resources three and six, which are the two bottlenecks.

10. The time between failures improvement strategy towards the two CCRs: This strategy aims to improve the time between failures in $12.5 \%$ at resources three and six, which are the two bottlenecks. 
The strategies were created to understand and compare the behavior of the focused strategy on one CCR (strategies 1, 2 and 5), distributed strategy (strategies 3, 4 and 6), hybrid strategy (strategies 7 and 8), and strategy directed towards the two CCRs (strategies 9 and 10).

The data was collected between March and December of 2018. The manufacturing process is a flow shop with seven workstations and two operators, in an industrial control and automation company, which process 13.690 units on average per month. In Figure 2 is possible to see the processing time (minute/unit) and utilization (\%) of each machine before any improvement was done, in this paper this state will be referred to as base scenario. As we can see, the process studied has two CCRs, workstation 3 (99.4\% of utilization) and workstation 6 (95.5\% of utilization).

Data used for simulation was obtained in three different ways. The processing time came from the average of several measurements of operating time in each machine. Demand was used the mean value of demand per month, worked time, the time between failures, time to repair, setup time, defect rates were obtained from the operations management department. Information about variability that was not possible to obtain was used as theoretical value. Table 2 expresses each variable and the initial value used in the simulation.

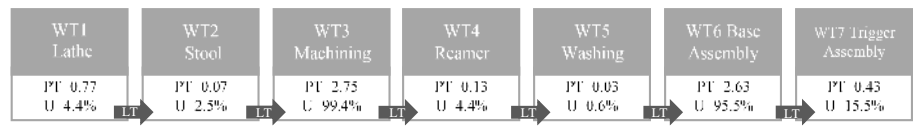

Figure 2 Flowshop Environment

Table 2 Initial Value used in Simulation

\begin{tabular}{|l|c|c|c|c|c|c|c|c|}
\hline \multicolumn{1}{|c|}{ Variables } & \multicolumn{7}{c|}{ Initial Values } \\
\cline { 2 - 9 } & WT1 & WT2 & WT3 & WT4 & WT5 & WT6 & WT7 \\
\hline Mean demand (units/month) & \multicolumn{7}{|c|}{13,690} \\
\hline Worked time (hours/month) & \multicolumn{7}{|c|}{} \\
\hline Mean time between failure (hours) & 380 & - & 95 & - & - & 47 & 380 \\
\hline Mean time to repair (minutes) & 60 & - & 120 & - & - & 30 & 10 \\
\hline Mean setup time (minutes) & 10 & 0 & 30 & 0 & 0 & 4.98 & 4.98 \\
\hline Mean defect rate (\%) & 0 & 0 & 0 & 0 & 0 & 2 & 0 \\
\hline Mean processing time (minute/unit) & 0.77 & 0.07 & 2.75 & 0.13 & 0.03 & 2.63 & 0.43 \\
\hline Lot size (unit) & 86 & 600 & 600 & 600 & 300 & 600 & 600 \\
\hline Setup time variability & 0.2 & 0.2 & 0.2 & 0.2 & 0.2 & 0.2 & 0.2 \\
\hline Time to repair variability & 0.2 & 0.2 & 0.2 & 0.2 & 0.2 & 0.2 & 0.2 \\
\hline Processing time variability & 0.2 & 0.2 & 0.25 & 0.19 & 0.2 & 0.63 & 0.11 \\
\hline
\end{tabular}

In Table 2 it is possible to observe that workstation two, four, and five has no value in mean time between failure and mean time to repair, it is because it would be an insignificant value. Section 4 presents the simulation results.

\subsection{Results}

\section{Simulation Results}

Aiming to compare the effect of each strategy on the lead time, it was used the gap concept. The gap can be defined as the difference between lead time after 
improvement and initial lead time divide by initial lead time. It shows in percentage how much one strategy can reduce the lead time (equation 2).

$G A P=\frac{\left(L T_{1}-L T_{0}\right)}{L T_{0}}$

where,

$\mathrm{LT}_{0}$ is the lead time before any improvement;

$\mathrm{LT}_{1}$ is the lead time after the improvement.

Table 3 express the lead time of each strategy for each workstation and Table 4 reports the total lead time of each strategy and the gap in comparison with the base scenario.

Table 3 Lead Time in Minutes of each Machine

\begin{tabular}{|l|c|c|c|c|c|c|c|}
\hline \multicolumn{1}{|c|}{ Strategy } & WT1 & WT2 & WT3 & WT4 & WT5 & WT6 & WT7 \\
\hline Base Scenario & 1.32 & 0.71 & 2730.70 & 1.30 & 0.80 & 515.51 & 4.75 \\
\hline $\begin{array}{l}\text { Distributed time between failure } \\
\text { improvement }\end{array}$ & 1.32 & 0.71 & 1967.92 & 1.30 & 0.74 & 478.51 & 4.74 \\
\hline Hybrid time between failure improvement & 1.32 & 0.71 & 1916.07 & 1.30 & 0.80 & 490.57 & 4.75 \\
\hline $\begin{array}{l}\text { Distributed time to repair and between } \\
\text { failure improvement }\end{array}$ & 1.32 & 0.71 & 1875.75 & 1.30 & 0.77 & 465.67 & 4.74 \\
\hline $\begin{array}{l}\text { Resources 3 and 6 time between failure } \\
\text { improvement }\end{array}$ & 1.32 & 0.71 & 1843.82 & 1.30 & 0.80 & 471.91 & 4.74 \\
\hline Distributed time to repair improvement & 1.32 & 0.71 & 1784.08 & 1.29 & 0.80 & 452.93 & 4.73 \\
\hline Hybrid time to repair improvement & 1.32 & 0.71 & 1716.13 & 1.30 & 0.80 & 465.15 & 4.74 \\
\hline $\begin{array}{l}\text { Resource 3 and 6 time to repair } \\
\text { improvement }\end{array}$ & 1.32 & 0.71 & 1620.83 & 1.30 & 0.80 & 438.66 & 4.73 \\
\hline Focused time between failure improvement & 1.32 & 0.71 & 1415.16 & 1.30 & 0.80 & 465.17 & 4.74 \\
\hline $\begin{array}{l}\text { Focused time to repair and time between } \\
\text { failure improvement }\end{array}$ & 1.32 & 0.71 & 1225.95 & 1.29 & 0.80 & 437.08 & 4.74 \\
\hline Focused time to repair improvement & 1.32 & 0.71 & 1044.21 & 1.29 & 0.80 & 409.55 & 4.74 \\
\hline
\end{tabular}

Table 3 shows the lead time of each machine after the improvement strategy and in the base scenario before any improvement strategy be implemented. It is possible to do see that in every strategy the only resource with a significant variation in lead time was the capacity constraint resources, machines three and six.

Table 4 shows that the best strategy is the focused time to repair improvement with a reduction, compared with the base scenario, of $55 \%$. In addition, it is possible to see the hybrid improvement in time to repair as a good option, in case a $25 \%$ reduction in time to repair is not viable. Table 5 presents a similar analyze, but for the utilization of the stronger CCR (workstation 3). 
Table 4 Total Lead Time of each Scenario

\begin{tabular}{|l|c|c|}
\hline \multicolumn{1}{|c|}{ Strategy } & Total lead time & GAP \\
\hline Base Scenario & 3255.08 & $0 \%$ \\
\hline Distributed time between failure improvement & 2455.24 & $25 \%$ \\
\hline Hybrid time between failure improvement & 2415.51 & $26 \%$ \\
\hline Distributed time to repair and between failure improvement & 2350.25 & $28 \%$ \\
\hline Resources 3 and 6 time between failure improvement & 2324.60 & $29 \%$ \\
\hline Distributed time to repair improvement & 2245.87 & $31 \%$ \\
\hline Hybrid time to repair improvement & 2190.15 & $33 \%$ \\
\hline Resource 3 and 6 time to repair improvement & 2068.35 & $36 \%$ \\
\hline Focused time between failure improvement & 1889.20 & $42 \%$ \\
\hline Focused time to repair and time between failure improvement & 1671.89 & $49 \%$ \\
\hline Focused time to repair improvement & 1462.61 & $55 \%$ \\
\hline
\end{tabular}

Table 5 Utilization of the Strongest CCR (Workstation 3) each Scenario

\begin{tabular}{|l|c|c|}
\hline \multicolumn{1}{|c|}{ Strategy } & Utilization & GAP \\
\hline Base Scenario & $99.39 \%$ & $0.00 \%$ \\
\hline Distributed time between failure improvement & $99.20 \%$ & $0.18 \%$ \\
\hline Hybrid time between failure improvement & $99.19 \%$ & $0.20 \%$ \\
\hline Distributed time to repair and between failure improvement & $99.19 \%$ & $0.19 \%$ \\
\hline Resources 3 and 6 time between failure improvement & $99.16 \%$ & $0.23 \%$ \\
\hline Distributed time to repair improvement & $99.19 \%$ & $0.20 \%$ \\
\hline Hybrid time to repair improvement & $99.17 \%$ & $0.22 \%$ \\
\hline Resource 3 and 6 time to repair improvement & $99.13 \%$ & $0.25 \%$ \\
\hline Focused time between failure improvement & $98.98 \%$ & $0.41 \%$ \\
\hline Focused time to repair and time between failure improvement & $98.94 \%$ & $0.45 \%$ \\
\hline Focused time to repair improvement & $98.88 \%$ & $0.51 \%$ \\
\hline
\end{tabular}

In Table 5 is possible to note that the strategies that achieved the best results were the ones that had a greater reduction on the strongest CCR (workstation 3) utilization. The reduction of utilization benefits the total lead time since it reduces the queue time and respectively the lead time (Hopp and Spearman, 2008). The strategy which achieved the best result was the focused time to repair improvement, and as we can see in Table 5, this strategy has a lower utilization level. Therefore, this corroborates Hopp and Spearman (2008) statement regarding the importance of decrease the utilization to reduce the lead time.

\subsection{Discussion}

The configuration studied in this paper is considered an unbalanced flow shop line with two CCRs. The CCRs were at stations 3 and 6 . There is no consensus in the literature regarding the best position of the CCRs. Caridi et al. (2006) explain that among the unbalanced strategies, the best results are given when the bottleneck is located at the end of the system: moving the bottleneck upstream leads to a productivity reduction since the stations located downstream the bottleneck are 
affected by bottleneck delays and production blocking. However, they explain that with a growing number of products and high variability, the strategies that locate the bottleneck upstream improves their results. Kadiapasaoglu et al. (2000) argue that the CCR at the gate of the line improves the system performance.

The manufacturing line analyzed had a coefficient of variability (0.2), which according to Hopp and Spearman (2008) is a low coefficient. Also, we considered a flow shop line with two CCRs, one at station 3 and the other at station 6 . As we can see in several papers (Caridi et al., 2006; Godinho Filho and Uzsoy, 2013; Godinho Filho and Utiyama, 2016; Kadiapasaoglu et al., 2000) the position of the bottleneck affects the performance. In the line studied, the strongest CCR (workstation 3 ) is in the middle of the line and has low variability. Therefore, the CCR at the third position affects the performance downstream, including the second CCR (workstation 6). A different configuration with the bottleneck at the end of the line is suggested in the literature as a better alternative. Future research can be performed aiming to understand the effects of a growing number of products and different positions of the two CCRs.

The strategies more focused on the CCRs had the best results. This was expected as we can see the difference between CCRs and non CCRs are higher than (15\%). According to Godinho Filho and Utiyama (2015) in lines with the presence of strong CCRs, focused strategies outperform distributed ones. Also, the hybrid strategies presented good results, better than distributed ones, and can be suggested as good strategies to be used, especially when it is difficult or impossible to improve the CCRs. Regarding the hybrid strategy, as we can see in Table 3, the results show a great gap of improvement. The logic of improvement focused on the three first workstations diminish the utilization of the strongest CCR. This may change the position of the strongest CCR to the sixth station which according to the literature, increases the performance of the line. Future studies can be conducted aiming to understand the possibility of floating bottlenecks and how to allocate improvements properly in this scenario.

\section{Conclusions}

This work aimed to study different strategies regarding the allocation of improvement programs on shop floor variables aimed at lead time reduction. We conducted simulations using the System Dynamics-Factory Physics model in a flow shop environment with seven workstations and 4 models of one product. The present study provides some contributions in terms of implications for academic and industrial environments. We divided our conclusions into two main topics: 5.1, implications for academic environments, and 5.2, implications for industrial environments.

\subsection{Contributions to the Academic Environment}

The reduction of lead using the Factory Physics and System Dynamics concepts has been extensively addressed in production management literature. We aim to contribute with this literature regarding lead time reduction, especially studying different strategies of allocation of improvement programs on shop floor variables. In this paper, we studied ten different strategies for improvement programs. An important contribution to the academy in this paper is the hybrid approach, which proposes a new way to direct the efforts of improvements. Also, the study with two 
strong CCRs (more than $95 \%$ of utilization) is an important contribution to the literature. Another important contribution is the problem of allocation with two CCRs and the possibility of having floating bottlenecks, as we suggested the best improvement strategies considering these two possibilities. Our paper aimed to contribute in this direction.

\subsection{Contributions for the Industrial Environment}

The main goal of this paper was to identify the best strategy to reduce lead time in a flow shop line, the results found are in agreement with the literature, but bringing a contribution compared to previous studies because it has two capacity restrained resources. Godinho Filho and Utiyama (2015) proposed an algorithm that enables production managers in a practical situation to make a proper choice among the different allocation strategies for improvement. They stated that for an unbalanced line, CCR with high utilization and a large difference in utilization between CCR and non CCRs (more than 15\%) the focused investment on the CCR must be performed. For situations in which is not possible to conduct this large investment on the CCR they suggest the Hybrid approach.

Our findings corroborate this finding and also add a new direction as we can state, for the time to repair and time between failures improvement that: for an unbalanced line with two CCRs with high utilization and a large difference in utilization between CCRs and non CCRs (more than 15\%) and which is impossible to perform a large investment on the CCR, companies should use hybrid approaches. Our results showed that both, hybrid time to repair improvement and hybrid time between failures improvement, delivered the best results compared to their respective distributed strategies.

The main limitations of this study are mainly regarding the flow shop analyzed. Future work can further investigate different flow shop configurations like a varying number of workstations, with different numbers of products or even different positions of the two CCRs.

\section{References}

1. Adane, T. F., Bianchi, M. F., Archenti, A., \& Nicolescu, M. Application of system dynamics for analysis of performance of manufacturing systems. Journal of Manufacturing Systems, 53, 212-233, 2019. https://doi.org/10.1016/j.jmsy.2019.10.004

2. Alfineto, J. J. M; Amancio, I. R.; Rosa, N. C.; Utiyama, M. H. R.; Estratégia de melhoria híbrida em um ambiente flowshop para redução do lead time. Proceedingsof Encontro nacional de engenharia de produção, 2019.

3. Blackstone Jr. J.H., Cox J.F. Designing unbalanced lines-understanding protective capacity and protective inventory. Production Planning and Control 13(4):416-423, 2002. https://doi.org/10.1080/09537280110121091

4. Betterton C.F., Cox J.F. Espoused drum-buffer-rope flow control in serial lines: a comparative study of simulation models. International Journal of Production Economics 117:66-79, 2008. https://doi.org/10.1016/j.ijpe.2008.08.050

5. Caridi M, Cigolini R, Farina V. Designing unbalanced paced lines: a conceptual model and an experimental campaign. Production Planning and Control 17(5):464-479, 2006. https://doi.org/10.1080/09537280600764394 
6. Christopher, M. Logistics and supply chain management. Financial Times/Irwin Professional Pub., 1992.

7. Craighead CW, Patterson JW, Fredendall LD Protective capacity positioning: impact on manufacturing cell performance. European Journal of Operational Research 134(v.2):425-438, 2001. https://doi.org/10.1016/S03772217(00)00266-6

8. Ericksen, P.D.; Stoflet, N.J.; Suri, R. Manufacturing Critical-path time (MCT): The QRM Metric for Lead time. Technical Report, Center for QRM, Wisconsin - Madison, 2007.

9. Fisel, J., Exner, Y., Stricker, N., \& Lanza, G. Changeability and flexibility of assembly line balancing as a multi-objective optimization problem. Journal of Manufacturing Systems, 53, 150-158, 2019. https://doi.org/10.1016/j.jmsy.2019.09.012

10. Forrester J.W. Industrial dynamics. Productivity Press, Portland, p 464p, 1961.

11. Godinho Filho, M.; Barco, C. F. A framework for choosing among different lean-based improvement programs. International Journal of Advanced Manufacturing Technology, 81(1-4), 183-197, 2015.

12. Renna, P. Allocation improvement policies to reduce process time based on workload evaluation in job shop manufacturing systems. International Journal of Industrial Engineering Computations 8 (3), 373-384. 2017.

13. Godinho Filho, M.; Utiyama, M. H. R. Comparing different strategies for the allocation of improvement programmes in a flow shop environment. Springer London, International Journal of Advanced Manufacturing Technology, 2015.

14. Godinho Filho, Moacir; Utiyama, Marcel H. R. Comparing the effect of different strategies of continuous improvement programmes on repair time to reduce lead time. International Journal of Advanced Manufacturing Technology, 87(1-4), 315-327, 2016.

15. Godinho Filho M, Uzsoy R. The effect of shop floor continuous improvement programs on lot size-cycle time relationship for a multi- product singlemachine environment. International Journal of Advanced Manufacturing Technology 52(5-8):669-681, 2011.

16. Godinho Filho M, Uzsoy R. The impact of simultaneous continuous improvement in set up time and repair time on manufacturing cycle times under uncertain conditions. International Journal of Production Research 51(2):447464, 2012. https://doi.org/10.1080/00207543.2011.652261

17. Godinho Filho, M.; Uzsoy, R. The impact of simultaneous continuous improvement in setup time and repair time on manufacturing cycle times under uncertain conditions. London, International Journal of Production Research, 51(2), 447-464 2013. https://doi.org/10.1080/00207543.2011.652261

18. Goldratt, E. M.; Cox, J. A Meta, um processo de melhoria contínua. $2^{\mathrm{a}}$ ed. São Paulo, Nobel, 2009.

19. Guimaraes A.A., Godinho Filho M, Oprime P. Guiding improvement programs towards lead-time reduction in a single-machine environment. International Journal of Advanced Manufacturing Technology. doi:10.1007/s00170-012-4475, 2013. 
20. Hadjinicola G. C., Soteriou A.C. Reducing the cost of defects in multistage production systems: a budget allocation perspective. European Journal of Operational Research145:621-634, 2003. https://doi.org/10.1016/S03772217(02)00216-3

21. Hong J.D., Hayya J.C. Joint investment in quality improvement and setup reduction. Computers \&Operations Research 22:567-574, 1995. https://doi.org/10.1016/0305-0548(94)00054-C

22. Hopp W.J.; Spearman M.L. Factory physics: foundations of manufacturing management, $3^{\mathrm{a}}$ th edn. McGraw Hill HigherEducation, Nova York, 720p., 2008.

23. Martins, P. G., Laugeni, F. P. Administração da produção. Editora Saraiva. $2^{\mathrm{a}}$ edição. São Paulo, 2006.

24. Kadipasaoglu S.N., Xiang W, Hurley S.F., Khumawala B.M. A study on the effect of the extent and location of protective capacity in flow systems. International Journal of Production Economics 63:217-228, 2000 https://doi.org/10.1016/S0925-5273(99)00020-1

25. Rau H, Chu Y.H., Cho K.H. Layer modelling for the inspection allocation problem in re-entrant production systems. International Journal of Production Research 43(17):3633-3655, 2005. https://doi.org/10.1080/13629390500124515

26. Renna, P.; Ambrico, M. The allocation of improvement programs in a flow shop for single and multi-products: a simulation assessment. International Journal of Agile Systems and Management, 12(3), 228-244, 2019.

https://doi.org/10.1504/IJASM.2019.101365

27. Slack, N.; Chambers, S.; Johnston, R. Operations management. Pearson education, 2010.

28. Suri, R.; Quick Response Manufacturing: A companywide approach to reducing lead times. Portland: Productivity Press, 1998.

29. Utiyama, M. H. R.; Moura, M. B.; Costa, E. P. Estudo da influência da melhoria conjunta no tempo de setup e tempo de reparo no lead time: uma simulação em ambiente flowshop com um recurso restritivo de capacidade. Proceedingsof Encontro nacional de engenharia de produção, 2017.

30. Womack, J.P., Jones, D.T., \& Ross, D. The machine that changed the world. Harper Perennial, New York, 1990.

\section{About Our Authors}

Marcel Heimar Ribeiro Utiyama is a professor in the Department of Industrial Engineering at FEI University. He received his BS, MS and $\mathrm{PhD}$ from Federal University of São Carlos (Brazil). Professor Utiyama was a visiting scholar in the Department of Industrial and Systems Engineering, University of Tennessee (USA). His areas of interest are: lead time reduction, Theory of Constraints, Quick Response Manufacturing, production planning and control, 4.0 Industry, lean manufacturing and continuous improvement.

Fernanda Caveiro Correia is a master candidate in Engineer Graduate Program at FEI University with focus on digital transformation and process improvements. She received her bachelor's degree in Production Engineering at FEI University. Fernanda work as a consultant at Management Solutions. Her areas of interest are: 
Process improvement, lead time reduction, Theory of Constraints, 4.0 Industry, and digital transformation.

Dário Henrique Alliprandini is a professor in the Department of Production Engineering at FEI University, Sao Bernardo do Campo, Brasil. He received the BS in Mechanical Engineering and his MS and PhD from University of Sao Paulo. His research interests focus on operations management, continuous improvement, lean production and product development processes. 